\title{
A New Biosensor to Enumerate Bacteria in Planktonic and Biofilm Lifestyle
}

\author{
Maria De Giusti ${ }^{2}$, Francesca Berlutti ${ }^{1}$, Fabrizio Pantanella ${ }^{1}$, \\ Lucia Marinelli ${ }^{2}$, Alessandra Frioni ${ }^{1}$, Tiziana Natalizi ${ }^{1}$, \\ Daniela Tufi ${ }^{2}$ and Piera Valenti ${ }^{1}$ \\ Sapienza University of Rome, Faculty of Pharmacy and Medicine \\ Department of Public Health and Infectious Diseases \\ ${ }^{1}$ Microbiology Unit, \\ ${ }^{2}$ Hygiene Unit \\ Italy
}

\section{Introduction}

Remarkable interest for human health concerns the microbiological risk assessment due infections by bacteria possessing the ability to adhere to host cell or abiotic surfaces as well as to live in aggregated and biofilm lifestyle. Biofilm is multicellular bacterial community held together by a self-produced extracellular matrix in response to several factors. These factors may include recognition of specific or non-specific attachment sites on cell surfaces, electrostatic interactions on abiotic surfaces, nutritional cues, or in some cases, exposure to stress conditions in the environment as well as into the host.

Biofilm lifestyle is comparatively more common than the planktonic one and it has been shown that biofilm plays a crucial role in human health (Brady et al., 2008; Bryers, 2008). As matter of fact, the eradication of bacterial biofilm by administration of antibiotics often fails due to the high drug resistance of bacteria in this lifestyle. Since 2008, European Centre for Disease Prevention and Control reports epidemiological data on the increasing of antimicrobial resistance constituting an important concern in public health hazard.

For this reason, rapid assays to determine biofilm susceptibility to antibacterial drugs can significantly improve the outcome of infected patients by enabling a fast selection of efficient antibiotic treatments, thus decreasing the period and the related costs of hospitalization, as well as the incidence of morbidity and mortality (Gfeller et al., 2005).

Therefore, a fundamental prerequisite in studying, counteracting and eradicating biofilm is the possibility to quantify the actual number of bacteria involved. Bacterial counts have deep implications in microbiological diagnosis and therapeutic treatments (Bryers, 2008), in water and food quality analysis (Ramalho et al., 2001; Lee et al., 2007; Rueckert et al., 2005), in environmental applications and consumers' safety.

The standard method used to evaluate the number of bacteria, based on determination of Colony Forming Units (CFUs) (ISO method), can be considered fully appropriate only when bacteria are in planktonic lifestyle but it is unreliable to count bacteria in aggregated, adherent and biofilm lifestyle (Berlutti et al., 2003, Pantanella, 2008; Berlutti, 2008 a; Frioni, 
2010). Even if different analytical strategies have been attempted to enumerate bacteria in biofilm, the detection of the actual number of bacteria in aggregated, adherent and biofilm lifestyle is still a great challenge for microbiologists.

The analytical assays alternative to CFU count have been classified in direct and indirect methods.

Direct methods including microscopic observation of bacteria adherent to surfaces through the use of optical, scanning electron, and transmission electron microscopes (Verheyen et al. 1993; John et al. 2001; Vacheethasanee et al. 2000) have been employed. Two main inadequacies characterize microscopic examinations: assessing cell viability and counting bacteria in aggregated or biofilm lifestyle. However, the detection of bacterial viability can be obtained by microscopic observation of the samples stained with specific fluorescent stain which allows highlighting viable bacteria (Boulos et al.1999; Hope et al. 2002). In particular, the LIVE/DEAD Viability Kit (Bac-Light) together with laser scanning confocal microscopy is able to reliably discriminate live from dead adherent bacteria (Gottenbos et al., 2002). On the contrary, the enumeration of adherent bacteria in aggregated and biofilm lifestyle through microscopic examinations is unreliable even when several microscopic fields are evaluated. As matter of fact, Atomic Force Microscopy has well shown biomaterial's imperfections which influence bacterial colonization and biofilm development different from microscopic field to field (Dorobantu, 2010).

Indirect methods suggest to detach bacteria in adherent and biofilm lifestyle by vortex or sonication and successively to count detached bacteria by CFU counts (Ceri et al., 1999; Sandoe et al., 2006). These procedures present disadvantages as they may not detach all bacteria or may alter bacterial viability leading to erroneous counts.

Other indirect methods count bacteria in biofilm through assays based on staining the firmly adherent cells (Christensen et al., 1985) or on spectrophotometrically measuring the dye eluted from stained bacteria (Merritt et al., 1998). These methods, too, are subject to uncertainties: the bacteria could be non homogeneously stained, or the dye also could be adsorbed and difficultly eluted from abiotic materials.

Indirect assays counting bacteria on the basis of their metabolism as the biologic reduction of the redox indicator 2,3,5 triphenyl tetrazolium chloride by metabolically active microorganisms or colorimetric detection of $\mathrm{CO}_{2}$ produced by viable microorganisms (Bochner et al., 1977; Thorpe et al., 1990) are semi-quantitative methods.

If this were not enough, there is another pivotal problem for human health: the bacterial count and the antibiotic therapy against bacteria adherent in biofilm on the catheters or medical devices (Bestul and Vandenbussche, 2005; Falagas et al., 2007). Usually, the bacterial count is not executed and antibiotic treatment of catheter-related infections is based on antibiotic susceptibility test performed on planktonic counterpart detached from catheters or medical devices instead of on biofilm (Ceri et al., 1999; Sandoe et al., 2006). It is well known that microorganisms organized in biofilm exhibit higher levels of antibiotic resistance than in planktonic form, so that a great part of therapeutic regimens based on susceptibility of planktonic forms fails to eradicate biofilm infections (Carratalà, 2002; Pascual et al.,1993). Some laboratories employs the Calgary Biofilm Device, the most popular method (Ceri et al., 1999) which determines the minimal biofilm eradication concentration (MBEC) as the concentration of antibiotic killing $100 \%$ of bacteria in biofilm. Unfortunately, this method does not detect the actual number of bacteria in biofilm used as inoculum in MBEC tests. As inoculum size influences the results of susceptibility tests (Egervarn et al., 2007), MBEC values determined using the above mentioned methods, could be mistaken. 
Taken together the data reported, it is imperative to setup a reliable method to detect the number of bacteria in biofilm.

Here, we describe a novel biosensor, named BioTimer Assay (BTA), which allows easily counting bacteria in adherent, aggregated and biofilm lifestyle without any manipulation of samples.

\section{Biosensor - BioTimer Assay}

BioTimer assay (BTA) is a new biosensor that allows counting bacteria both in planktonic, aggregated, adherent and biofilm lifestyle. BTA employs original reagents containing specific indicators able to switch as a consequence of bacterial metabolism.

As matter of fact, living bacteria release one or more metabolites that induce color switching of BTA indicators. Therefore, BTA can be classified as an indirect method counting bacteria independently on their lifestyle (i.e.: planktonic, aggregated, adherent and biofilm lifestyle) by detecting the time required for indicator switching induced by a metabolic product specific for each bacterial genus. The time for color switching of indicators is inversely related to the number of living bacteria present in the sample. Interestingly, BTA is a simple, easy to perform method to count bacteria without any manipulation of samples.

At now two main indicators have been selected and added to specific original reagents of BTA: phenol red specific to count fermenting bacteria and resazurin to count nonfermenting bacteria.

The reagent, named BioTimer Phenol Red (BT-PR), contains phenol red and it appears clear and red after sterilization, i.e. in the absence of living bacteria (Fig. 1, insert of Panel A ) (Berlutti et al., 2003). In the presence of bacteria, BT-PR reagent switches red-to-yellow due to metabolism of fermenting bacteria. Optical absorbance of BT-PR in the absence or in the presence of bacteria is shown in Figure 1 (Panel A, continuous and dotted line, respectively). The other BTA reagent, named BioTimer Resazurin (BT-RZ) contains resazurin and it appears clear and blue after sterilization i.e. in the absence of living bacteria (Fig. 1, insert of Panel B) (Frioni et al., 2010). In the presence of bacteria, BT-RZ switches blue-to-pink due metabolism of non-fermenting bacterial. Optical absorbance of BT-RZ in the absence or in the presence of bacteria is shown in Figure 1 (Panel B, continuous and dotted line, respectively).

As above mentioned, the time required for color switch of BT-PR and BT-RZ reagents is inversely related to initial bacterial concentration. Therefore, the time required for color switching $\left(\mathrm{t}^{*}\right)$ determines the initial number of bacteria $\left(\mathrm{N}_{0}\right)$ present in a sample at time $=0$ $\left(\mathrm{t}_{0}\right)$ through specific correlation lines. To draw the correlation lines, serial dilutions of both fermenting and non-fermenting planktonic bacteria are counted by CFUs and used to inoculate BT-PR and BT-RZ reagents, respectively. The inoculated reagents are incubated at proper temperature and the color of the reagents monitored.

The switching time $\left(\mathrm{t}^{*}\right)$ needed for the color switching of BT-PR (red-to-yellow) and BT-RZ (blue-to-pink) reagents is recorded. The $t^{*}$ and the corresponding CFU counts are used to construct the correlation lines. All correlation lines are obtained by linear regression analysis, and linear correlation coefficients are calculated from the equation (1)

$$
r=\left(n \sum x y-\sum x \sum y\right) /\left(\operatorname{sqrt}\left(\left(n \sum x^{2}-\left(\sum x\right)^{2}\right)\left(n \sum y^{2}-\left(\sum y\right)^{2}\right)\right)\right) .
$$



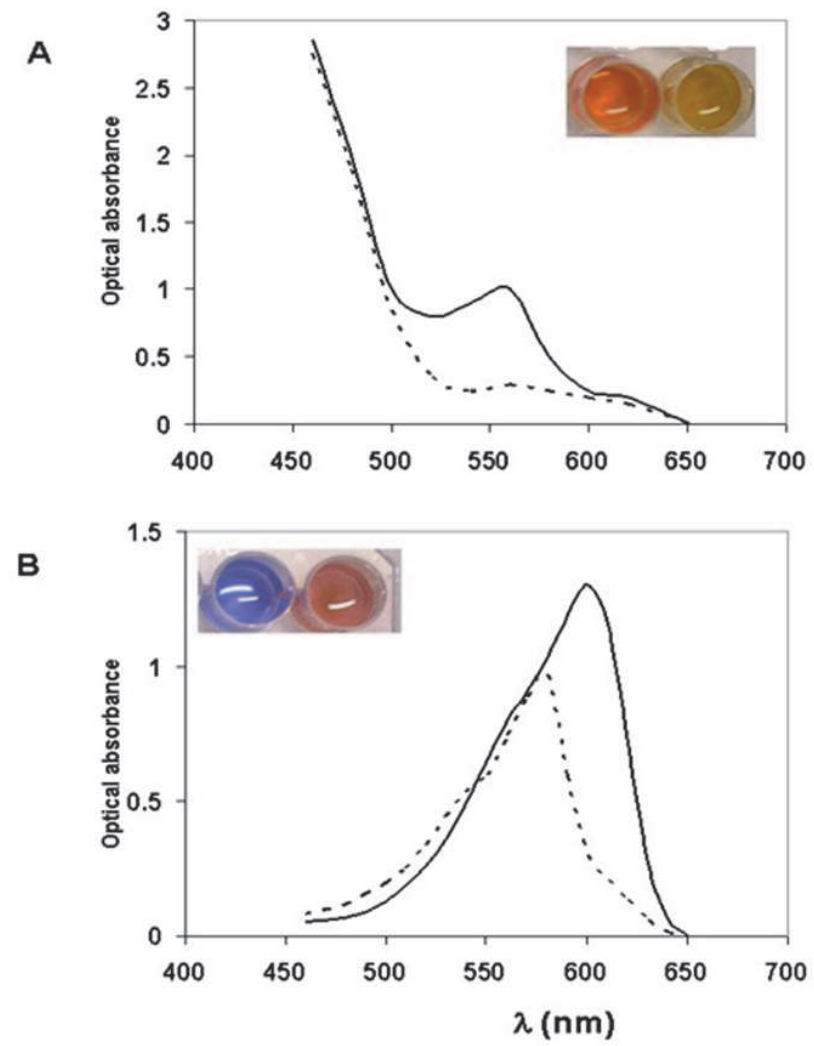

Fig. 1. Color switching of indicator specific for fermenting (A) and non-fermenting (B) bacteria contained in original reagents of BioTimer Assay (Frioni et al., 2010). Optical absorbance of BT-PR (Panel A) and BT-RZ (Panel B) indicators in the absence (solid line) or in the presence of bacteria (dotted line) at different $\lambda$ as well as the color of BT-PR and BTRZ reagents (insert of Panel A and Panel B, respectively) in the absence or in the presence of bacteria (left and right image of the inserts, respectively) are shown.

The switching time $t^{*}$ is inversely proportional to the logarithm of the initial value $N_{0}$, according to the following equation

$$
\mathrm{t}^{*}=-\mathrm{a} \log \mathrm{N}_{0}+\mathrm{b}
$$

where $a, b>0$ are correlation parameter depending on the environmental conditions and bacterial genus, respectively. In Figure 2, a typical correlation line is shown.

Several correlation lines have been drawn for different bacterial genera and species. In Table 1 the equations of correlation lines and the corresponding linear correlation coefficients to count fermenting and non-fermenting bacteria in several BTA applications are shown. The sensitivity of BTA theoretically corresponds to $\mathrm{N}_{0}=10-20$ CFUs, even if the stochastic fluctuations for low values of $\mathrm{N}_{0}$ will influence the standard deviation similarly to that observed using CFU method (Goel \& Richter-Dyn, 1974). 


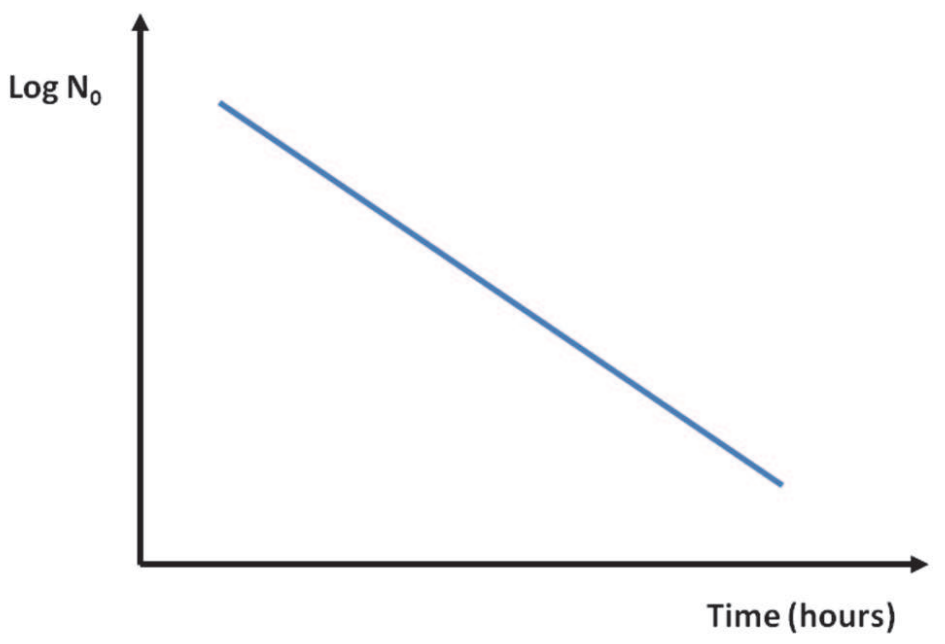

Fig. 2. BioTimer Assay correlation line. The typical BTA correlation line correlating the time $\left(t^{*}\right)$ for color switching of BTA indicator and the log of number of bacteria initially present in the samples $\left(\mathrm{N}_{0}\right)$ is described by the linear equation $t^{*}=-a \log \mathrm{N}_{0}+b$.

Moreover, the Eq (2) takes into account not only the $t^{*}$ of switching of different indicators, but also the composition of different reagents through "a" parameter. As shown in Figure 3 the correlation lines for Lactobacillus rhamnosus performed using BT-PR reagent containing glucose or lactose, as carbon source, differ only for "a" parameter involving the switching time $\left(t^{*}\right)$ for the same number of bacteria $\left(\mathrm{N}_{0}\right)$.

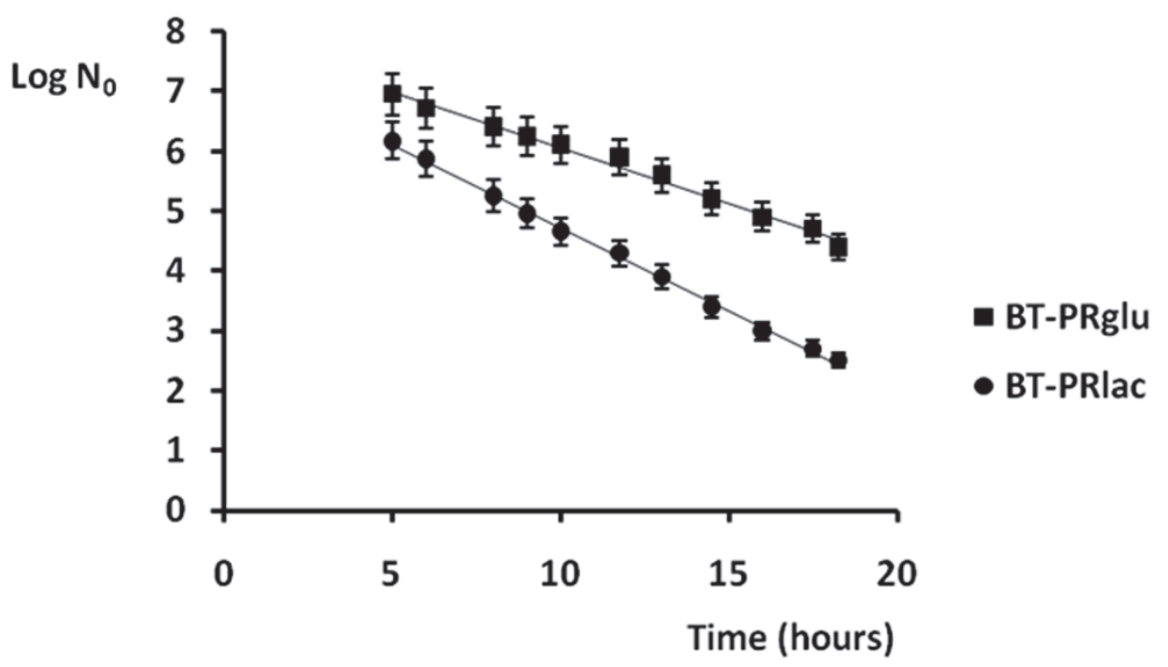

Fig. 3. Correlation lines of Lactobacillus acidophilus obtained using a BioTimer Assay Phenol Red (BT-PR) specific reagent with 1\% glucose (BT-PRglu) or 1\% lactose (BT-PRlac). 


\begin{tabular}{|c|c|c|c|c|c|}
\hline $\begin{array}{l}\text { Bacterial } \\
\text { species }\end{array}$ & $\begin{array}{c}\text { BTA } \\
\text { reagent }\end{array}$ & $\begin{array}{c}\text { Equation of } \\
\text { correlation line }\end{array}$ & $r$ & Application & Reference \\
\hline $\begin{array}{l}\text { Streptococcus } \\
\text { sobrinus }\end{array}$ & BT-RP & $-0.3056 x+8.2608$ & 0.9997 & $\begin{array}{l}\text { Adhesion to dental } \\
\text { polymers }\end{array}$ & $\begin{array}{l}\text { Berlutti et al., } \\
2003\end{array}$ \\
\hline $\begin{array}{l}\text { Streptococcus } \\
\text { oralis }\end{array}$ & BT-RP & $-0.301 x+9.0615$ & 0.9999 & $\begin{array}{l}\text { Adhesion to dental } \\
\text { polymers }\end{array}$ & $\begin{array}{l}\text { Berlutti et al., } \\
2003\end{array}$ \\
\hline \multirow{2}{*}{$\begin{array}{l}\text { Lactobacillus } \\
\text { acidophilus }\end{array}$} & BT-RPglu & $-0.1857 x+7.9174$ & 0.9903 & $\begin{array}{l}\text { Control of lyophilized } \\
\text { probiotic preparation }\end{array}$ & $\begin{array}{l}\text { Valenti et al., } \\
\text { personal } \\
\text { data }\end{array}$ \\
\hline & BT-RPlac & $-0.2773 x+7.4984$ & 0.998 & $\begin{array}{l}\text { Control of lyophilized } \\
\text { probiotic preparation }\end{array}$ & $\begin{array}{l}\text { Valenti et al., } \\
\text { personal } \\
\text { data }\end{array}$ \\
\hline \multirow{2}{*}{$\begin{array}{l}\text { Staphylococcus } \\
\text { aureus }\end{array}$} & BT-RP & $-0.5903 x+8.7219$ & 0.9973 & $\begin{array}{l}\text { Adhesion to dental } \\
\text { polymers }\end{array}$ & $\begin{array}{l}\text { Berlutti et al., } \\
2003\end{array}$ \\
\hline & BT-RPMH & $-0.597 x+10.28$ & 0.9990 & $\begin{array}{l}\text { Antibiotic } \\
\text { susceptibility of biofilm }\end{array}$ & $\begin{array}{l}\text { Pantanella et } \\
\text { al., } 2008\end{array}$ \\
\hline $\begin{array}{l}\text { Staphylococcus } \\
\text { epidermidis }\end{array}$ & BT-RPMH & $-0.633 x+9.267$ & 0.9980 & $\begin{array}{l}\text { Antibiotic } \\
\text { susceptibility of biofilm }\end{array}$ & $\begin{array}{l}\text { Pantanella et } \\
\text { al., } 2008\end{array}$ \\
\hline $\begin{array}{l}\text { Enterococcus } \\
\text { faecalis }\end{array}$ & BT-RP & $-0.4767 x+10.022$ & 0.9975 & $\begin{array}{l}\text { Laser disinfection of } \\
\text { dental root canals }\end{array}$ & $\begin{array}{l}\text { Berlutti et al., } \\
\text { personal } \\
\text { data; Telesca, } \\
\text { Master } \\
\text { Thesis, } 2010\end{array}$ \\
\hline \multirow{2}{*}{ Escherichia coli } & BT-RP & $-0.9678 x+10.347$ & 0.9955 & $\begin{array}{l}\text { Adhesion to dental } \\
\text { polymers }\end{array}$ & \begin{tabular}{|l} 
Berlutti et al., \\
2003
\end{tabular} \\
\hline & FBTA & $-0.8723+14.428$ & 0.9970 & $\begin{array}{l}\text { Fecal contamination of } \\
\text { food }\end{array}$ & $\begin{array}{l}\text { Berlutti et al., } \\
2008\end{array}$ \\
\hline $\begin{array}{l}\text { Pseudomonas } \\
\text { aeruginosa }\end{array}$ & BT-RZ & $-0.4675 x+8.5841$ & 0.9996 & $\begin{array}{l}\text { Adhesion to dental } \\
\text { polymers; } \\
\text { adhesion to SWCNT- } \\
\text { structured surfaces }\end{array}$ & $\begin{array}{l}\text { Berlutti et al., } \\
\text { 2003; } \\
\text { Frioni et al., } \\
2010\end{array}$ \\
\hline $\begin{array}{l}\text { Burkoldheria } \\
\text { cenocepacia }\end{array}$ & BT-RZ & $-0.415 x+9.018$ & 0.9610 & None & $\begin{array}{l}\text { Berlutti et al., } \\
\text { personal } \\
\text { data }\end{array}$ \\
\hline
\end{tabular}

Table 1. Correlation lines.

Likely, Eq.(2) takes into account also bacterial genera/species through " $b$ " parameter. As shown in Figure 4 the correlation lines for Staphylococcus aureus and Streptococcus sobrinus or $S$. oralis performed using the same BTA reagent differ only for " $b$ " parameter involving the different metabolic activity specific for each bacterial genera/species.

Summarizing, in the BTA applications, the number of living planktonic bacteria in a sample is determined inoculating the specific BTA reagent. The color switching of BTA indicator is monitored and the time $\left(\mathrm{t}^{*}\right)$ for color switching is recorded and used to determine the $\log \mathrm{N}_{0}$ through the specific correlation line. 


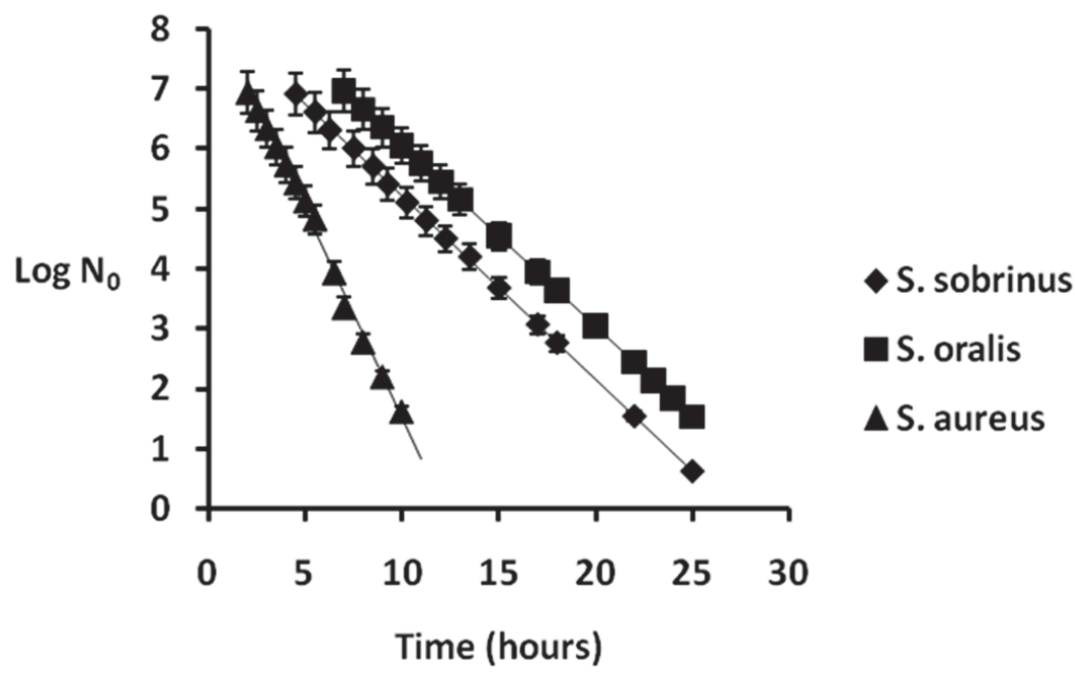

Fig. 4. Correlation lines of Streptococcus sobrinus, Streptococcus oralis and Staphylococcus aureus obtained using BT-PR reagent.

Similarly, it is possible to count bacteria in aggregated, adherent and biofilm lifestyle by inoculating BTA reagents with sample containing aggregated bacteria or solid supports/materials on which bacteria adhere or form biofilm (colonized material) without sample manipulation. As the Eq. 2 describes the correlation between the time for color switching of BTA indicators present in the original reagents and the CFUs $\left(\mathrm{N}_{0}\right)$ of planktonic bacteria, the number of bacteria in aggregated, adherent and biofilm lifestyle counted using BTA can be defined as planktonic-equivalent CFUs (PE-CFUs).

However, it is possible to object that the metabolic rate of the same bacterium in different lifestyle can be different and consequently the counts by BTA can be influenced by lifestyle. In order to answer to this objection, S. sobrinus has been chosen as bacterial model because it produces lactate as the principal end product of carbohydrate metabolism (Madigan, 2008; Burne, 1998), which is easily detectable by high performance liquid chromatography system (Berlutti, 2008; personal data). Planktonic and biofilm lifestyle S. sobrinus was cultured in complete medium for $24 \mathrm{~h}$ at $37^{\circ} \mathrm{C}$, in the absence or in the presence of glass beads, respectively. S. sobrinus, indeed, colonizing the glass beads forms biofilm in 24 hours of incubation. Both planktonic bacteria and colonized glass beads were used to inoculate BTPR reagents. The time for color switching of BT-PR reagents as well as the lactate concentrations ( $\left.\mathrm{c}_{\text {lac }}\right)$ at the moment of the color switching were recorded.

The values of lactate concentration $\mathrm{Clac}_{\text {ac }}$ at the moment of color switching of BT-PR reagents inoculated with different concentrations of planktonic $\mathrm{N}_{0}$ were similar and corresponded to a mean value of $770 \pm 33 \mathrm{mg} / 1$ (Table 2).

The values of $\mathrm{c}_{\text {lac }}$ at the moment of color switching of BT-PR reagents inoculated with 1, 5, 10 colonized beads were similar and corresponded to a mean value of $760 \pm 45 \mathrm{mg} / 1$ (Table 2). Therefore, the concentration of lactate needed for inducing color switching of the indicator is independent from bacterial lifestyle. The sole difference observed among the samples was the time required for color switching, the parameter pivotal for bacterial counts by BTA (Berlutti et al., 2008 a; Valenti, personal data). 


\begin{tabular}{|l|c|c|c|}
\hline Lifestyle & Inoculum & clac $(\mathrm{mg} / \mathrm{l})$ & $\mathrm{t}^{*}$ (hours) \\
\hline \multirow{3}{*}{ Planktonic $\left(\log \mathrm{N}_{0}\right)$ a } & 5 & $761 \pm 42$ & 10.2 \\
\cline { 2 - 4 } & 6 & $773 \pm 42$ & 7.5 \\
\cline { 2 - 4 } & 7 & $777 \pm 20$ & 4.5 \\
\hline \multirow{3}{*}{ Biofilm $\left(\mathrm{N}_{\mathrm{GB}}\right)$} & 1 & $805 \pm 48$ & 4.5 \\
\cline { 2 - 4 } & 5 & $710 \pm 52$ & 2.7 \\
\cline { 2 - 4 } & 10 & $740 \pm 45$ & 1.5 \\
\hline
\end{tabular}

Table 2. Lactate concentration ( $\left.\mathrm{Clac}_{\mathrm{lac}}\right)$ and switching time $\left(\mathrm{t}^{*}\right)$ of BT-PR reagents inoculated with Streptococcus sobrinus in planktonic and biofilm lifestyle. Legend: a planktonic inoculum is prepared from broth cultures; biofilm inoculum is obtained utilizing colonized glass beads $\left(\mathrm{N}_{\mathrm{GB}}\right)$.

Similarly to that demonstrated in counting planktonic bacteria by BTA, the time required for BTA indicator switching is inversely related to the increasing of colonized glass bead $\left(\mathrm{N}_{\mathrm{GB}}\right)$ number and consequently to the number of bacteria in biofilm (Table 2).

Therefore, the switching time $\mathrm{t}^{*}$ is inversely proportional to the logarithm of the initial $\mathrm{N}_{\mathrm{GB}}$, according to the following equation

$$
\mathrm{t}^{*}=-\mathrm{a}_{\mathrm{GB}} \log \mathrm{N}_{\mathrm{GB}}+\mathrm{b}_{\mathrm{GB}}
$$

which is equivalent to the Eq. (2) describing the correlation line for bacteria in planktonic lifestyle.

\section{BioTimer Assay applications}

It is important to again underline that the counts of bacteria in aggregated, adherent and biofilm lifestyle, through BTA, do not require any manipulation of the samples, and this characteristic represents an important advantage of BTA respect to other methods. However, in the absence of a validated reference method, the number of bacteria in aggregated, adherent and biofilm lifestyle carried out by BTA cannot be compared with those obtained by other methods of bacterial enumeration in biofilm. This lack is a disadvantage for all novel methods. Notwithstanding, BTA has been successfully applied to enumerate bacteria in biofilm adherent on abiotic materials, on different foods and recently, to detect the susceptibility of biofilm to antibiotics as well as the microbiological quality of nano-particles to be in vivo administered.

\subsection{BioTimer Assay to enumerate bacteria in adherent and biofilm lifestyle on abiotic materials}

The actual quantitative determination of bacteria in adherent and biofilm lifestyle on abiotic materials is a concern for microbiologists. BTA has been successfully employed to estimate bacterial population colonizing a variety of abiotic materials.

The first report concerned the evaluation of adhesion ability of different Gram-positive and Gram-negative species on different adhesive poly(HEMA)-based hydrogels to be utilized in dental restorative procedures (Berlutti et al., 2003). As matter of fact, the use of dental polymers is a standardized practice in dental restorative procedures. However, bacteria 
potentially causing oral pathologies may colonize these polymers. It is therefore of great importance to evaluate both the susceptibility of the polymers to colonization by resident and transient bacterial genera, and the importance of chemical factors triggering bacterial adhesion. The study reported data of adhesion efficiency and biofilm formation of $S$. sobrinus and Streptococcus oralis representing bacterial resident species, and Staphylococcus aureus, Escherichia coli, and Pseudomonas aeruginosa considered transient bacteria in the oral cavity. The dental polymers were prepared with 2-hydroxyethyl methacrylate (HEMA) and different molar ratios of 2-acrylamido-2-methylpropane-sulfonic acid (AMPS) and/or 2methacryloyloxyethyl-tri-methyl-ammonium chloride (METAC) co-monomers.

In conditions mimicking those present in the oral cavity, all tested bacteria showed similar adhesion percentages on the same dental polymer and different adhesion percentages on the different dental polymers (Fig. 5). As matter of fact, the physico-chemical characteristics of poly-HEMA based hydrogels are the major factors promoting bacterial adhesion. In particular, the adhesion efficiency increased with increasing water content in the swollen polymers and reached maximal values on cationic polymers. The highest adhesion efficiency was recorded for the polymer p(HEMAco-METAC) (10:1) that showed also the highest swelling ratio in double-distilled water.

BTA has been further employed in several microbiological studies in dentistry and, in particular, to demonstrate the antibacterial efficiency of laser treatment of experimental infections of dental root canals.

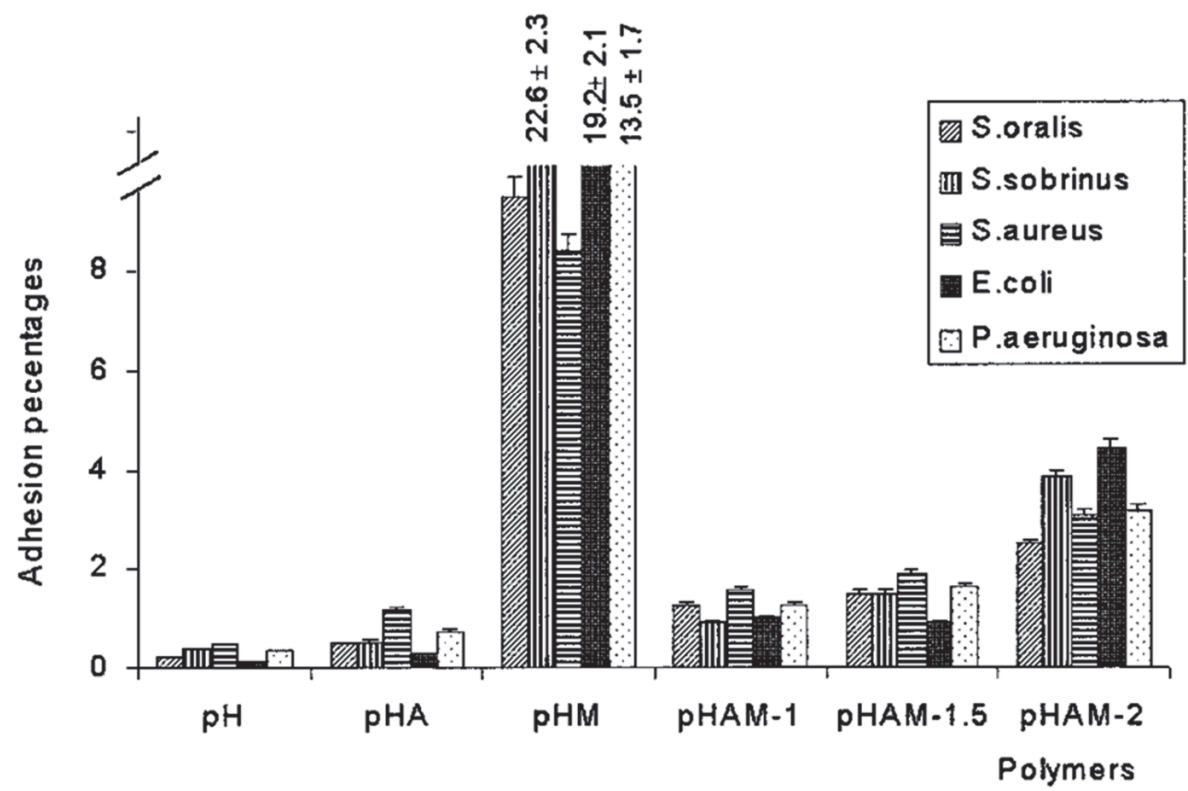

Fig. 5. Bacterial adhesion to different polymers. Adherent bacteria are expressed as percentages of the cells initially present in the saliva-polymer mixtures. The polymers used were: pH: p(HEMA); pHA:p(HEMA-co-AMPS) (10:1); pHM:p(HEMAco-METAC) (10:1); pHAM-1:p(HEMA-co-AMPS-co-METAC) (10:1:1); pHAM-1.5:p(HEMA-co-AMPS-coMETAC) (10:1:1.5); pHAM-2:p(HEMA-co-AMPS-co-METAC) (10:1:2). (Berlutti et al., 2003) 


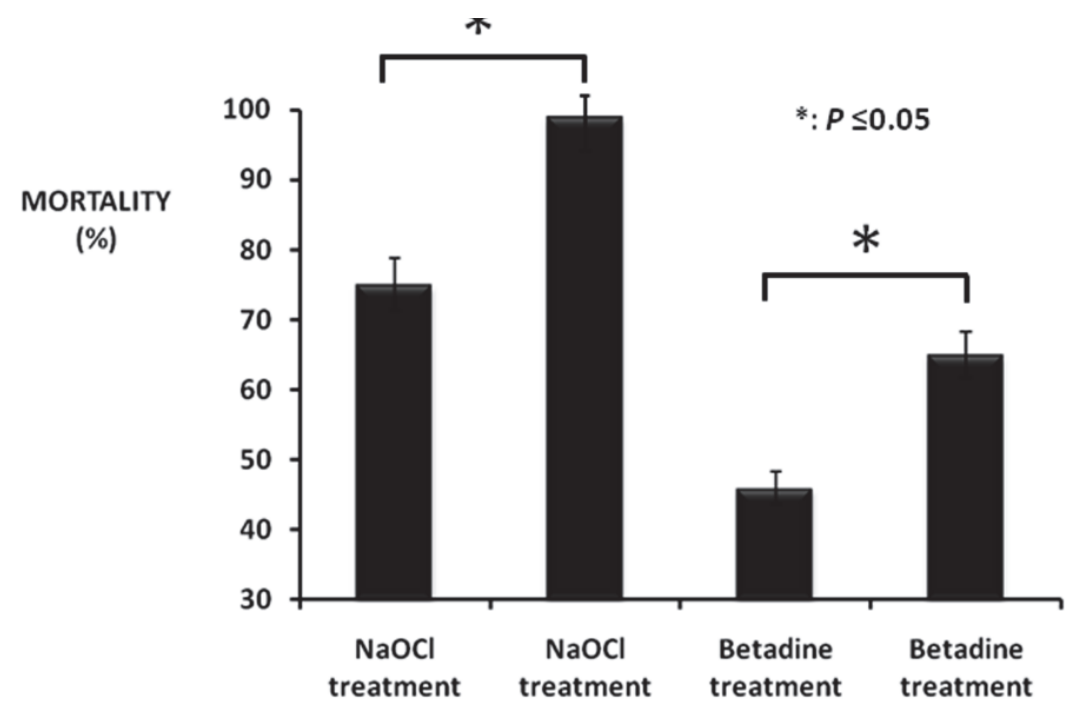

Fig. 6. Bactericidal activity of diode laser $808 \mathrm{~nm}$ treatment against Enterococcus faecalis CCM 2541 adherent on dental root canals. Dental roots were infected with Enterococcus faecalis CCM 2541( $2.5 \pm 0.7 \times 10^{6}$ CFUs). After 3 hours of incubation, dental root canals were treated with 808 diode alone or in combination with $\mathrm{NaOCl}$ or betadine.

It is well known that dental root canals may be infected with different bacteria causing endodontic as well as apical periodontitis and pulpitis. The treatment of canal and apical periodontal infections consists in eradicating microbes or in reducing the microbial load and preventing re-infection by orthograde root filling. The disinfectant treatment has a remarkably high degree of success even if it cannot be excluded some fail (Mohammadi \&Abbott, 2009; Nair 2004). Enterococcus faecalis is associated with a significant number of refractory endodontic infections (Vidana et al., 2010; Ricucci \& Siqueira, 2010). Recently, a different therapeutic approach for endodontic infections based on laser therapy has been exploited (Schwarz et al, 2009; Romeo et al., 2003). BTA has been applied, using a correlation line specific for E. faecalis, to evaluated the killing efficiency of the combined use of diode $808 \mathrm{~nm}$ laser and betadine or $\mathrm{NaOCl}$ disinfectants against E. faecalis adherent on dental root canals after 3 hours of contact (Table 1) (Berlutti \& Romeo, personal data). Results have showed that the both disinfectants did not kill all adherent bacteria while the combined use of disinfectants and diode 808nm laser significantly increased their antibacterial activity, even if at different extent (Fig. 6).

Further experiments were carried out to evaluate the efficiency of treatments carried out using diode 808nm and Er: YAG 2940nm laser against E. faecalis biofilm developed for 72 hours on dental root canals (Telesca V, European Master Degree On Oral Laser Applications Thesis). The results, obtained counting bacterial population in biofilm by BTA, showed that laser treatments significantly reduced bacterial number (Fig. 7).

\subsection{BioTimer Assay to enumerate Escherichia coli in planktonic, adherent and biofilm lifestyle on different foods and surfaces: applications in HACCP}

Food safety is a global health goal. U.S. Food and Drug Administration (FDA) has developed a comprehensive 'Food Protection Plan' in which food must be considered as a 


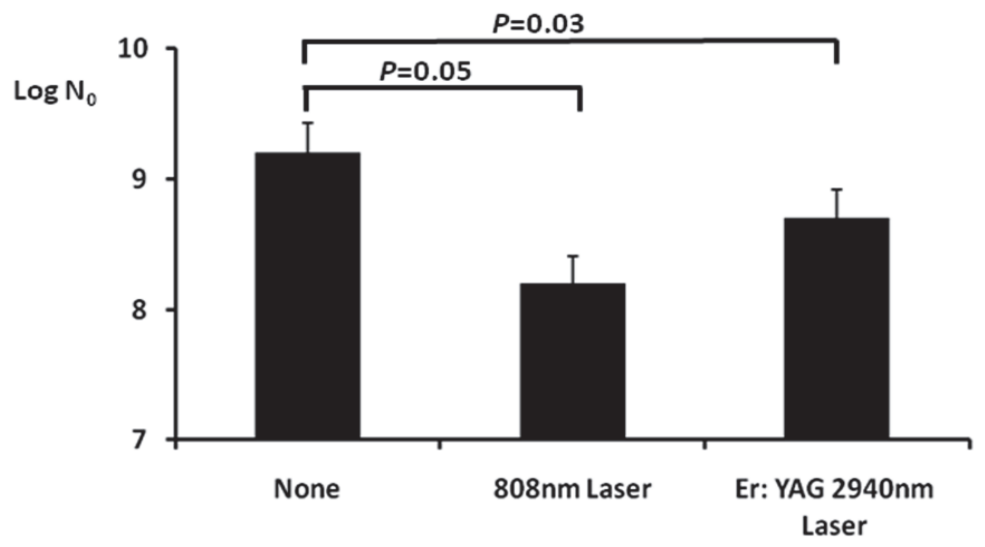

Fig. 7. Bactericidal activity of 808 diode and Er: YAG laser treatment on Enterococcus faecalis CCM 2541 biofilm developed on dental root canals. Dental roots were infected with Enterococcus faecalis CCM 2541 ( $2.5 \pm 0.7 \times 10^{6}$ CFUs). After 72 hours of incubation, dental root canals were not treated (CTRL) or treated with 808 diode or Er: YAG laser. P values $\leq 0.05$ were considered significant.

potential vehicle for intentional contamination (FDA, Food Protection Plan, 2007). Such intentional contamination of food could result in human or animal illnesses and deaths, as well as economic losses.

The European legislation through EC Regulation 852/2004 on the Hazard Analysis and Critical Control Point (HACCP) application in primary and secondary food productions indicates the systematic approach for food safety management. EC Regulation 2073/2005 followed by EC Regulation 1441/2007 identifies " microbiological criteria for food and foodstuffs" and indicated that "...foodstuffs should not contain microorganisms or their toxins or metabolites in quantities that present an unacceptable risk for human health".

In developed countries changes in the epidemiology of traditional infections have been observed: in USA in 2008 the incidence of Salmonella serotype Typhimurium is decreased, whereas the incidence of serotypes Newport, Mississippi, and Javiana is increased. In the same year in European Economic Area/European Free Trade Association countries, the two most common Salmonella serovars (S. enteritidis and S. typhimurium) representing $56 \%$ and $22 \%$, respectively, were found. Moreover, the increasing of incidence of re-emerging and emerging pathogens like Escherichia coli O157, Listeria monocytogenes, Campylobacter jejuni, Norovirus and Hepatitis A virus, responsible for majority of food-borne outbreaks was observed (De Giusti et al., 2007; Velusamy et al. 2010; MMWR, 2008; ECDC. 2008).

Therefore, the food industry is strongly involved in real methods to detect the presence of pathogenic microorganisms, as failure or delay in detecting bacterial pathogens may lead to a dreadful effect.

Preparation and handling of safe food products requires the observance of hazard analysis and critical control point (HACCP) principles including : 1- to carry out the hazard analysis; 2- to determine the critical control points (CCPs); 3 - to establish the critical limits; 4 - to monitor the procedures; 5 - to carry out the corrective actions; 6 - to verify the procedures, and 7- to establish record-keeping and documentation procedures (EC Regulation 852/2004). In particular, this 
Regulation reassesses the application of the HACCP procedure by extending it to the control of primary production and reinforces the role of Good Manufacturing Practice.

The Commission Regulation on the Microbiological Criteria for Foodstuffs (EC Regulation 1441/2007 amending EC Regulation 2073/2005) identifies Escherichia coli as indicator of good hygienical practice defining different limits of E. coli load in diverse foods and food handling procedures. Therefore, E. coli plays a pivotal role in performing corrective hygienic actions at CCPs to fit microbiological criteria of food safety as well as manufacturing, handling and distribution processes. The EC Regulation 1441/2007 indicates also the standard methods to count and identify E. coli (ISO 16649-2:2001). Conventional microbiological analyses (ISO methods) such as bacterial culture, colony forming unit (CFU) and other techniques as immunology-based and polymerase chain reaction-based methods have been used to evaluate food safety. However, all these techniques provide results after relatively long time spans (up to 72 hours) and many materials are needed. Moreover, ISO methods analyse a small amount of food samples (up to $0.1 \mathrm{~g}$ ) that may not be representative of the actual bacterial contamination and they not guarantee reproducible and real results except for bacteria in planktonic lifestyle.

As matter of fact, many bacterial pathogens are able to grow, survive and persist in foods as well as to adhere both to catering surfaces and utensils also in biofilm lifestyle (Wilks et al., 2005, 2006). Biofilm in foods shows high resistance to disinfectants or biocides (Byun et al.,2007), thus causing food borne infections and diseases in humans (Gandhi, 2007; Oliver, 2005).

In foods, standardized enumeration of bacteria is based on CFUs count and on the most probable number (MPN) method (EC Regulations 2073/2005 and 1441/2007). Even if MPN could overcome the problem of counting bacteria in biofilm, it cannot be applied to count bacteria on surfaces and, moreover, it is manual labour and time consuming. Therefore, the development of microbiological methods allowing rapid and reliable detection of bacteria in biofilm for evaluating bacterial contamination of food and surfaces is highly desirable.

For this purpose, BTA has been specifically modified for the detection of E. coli as biological indicator of faecal contamination of food and surfaces. The modified BTA, named FoodBTA (FBTA), utilizes the phenol red indicator, a reagent specific for E. coli, and its corresponding correlation line (Table 1).

FBTA has been used for the evaluation of E. coli recovery in 122 food and surface samples. FBTA results compared with those of reference method (CFU/g or $\mathrm{CFU} / \mathrm{cm}^{2}$, respectively) showed high overall agreement percentage $(97.54 \%)$ as identical results were obtained in 119 out 122 samples and discordant results concerned only three samples ( 1 food, 2 surfaces). Among the three discordant results, the food sample was positive using FBTA and negative using reference method. It should be underlined that FBTA allows analysing a 10-fold greater amount of food sample than reference method thus increasing the chance to detect $E$. coli contamination. Moreover, FBTA counts a greater E. coli number in 8 out 9 positive food samples than reference method. Concerning surface samples, the discrepancies could depend on fact that samples were collected in nearby surfaces that may be differently contaminated. The time required to achieve the results on E. coli contamination for all samples was 3-fold shorter using FBTA than reference method (Fig. 8, panel A). The trend of promptness in the results (Fig. 8, Panel B) clearly showed that FBTA may be considered very effective for HACCP application, as corrective actions at CCPs can be quickly taken (Berlutti et al., 2008b). Actually, using FBTA method, E. coli contamination can be detected in few hours and, in particular, the time will be shorter in the presence of higher than lower E. coli contamination. 
A

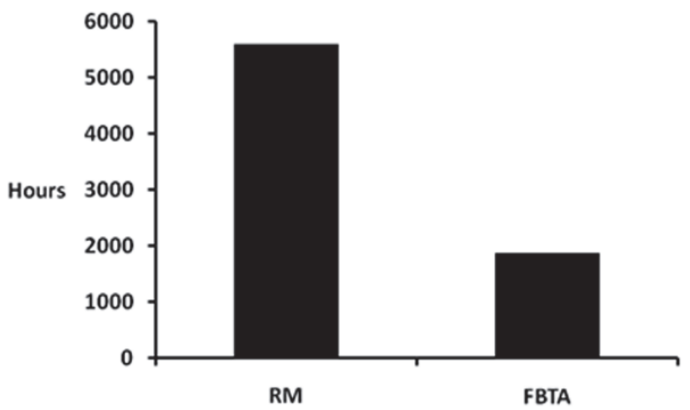

B

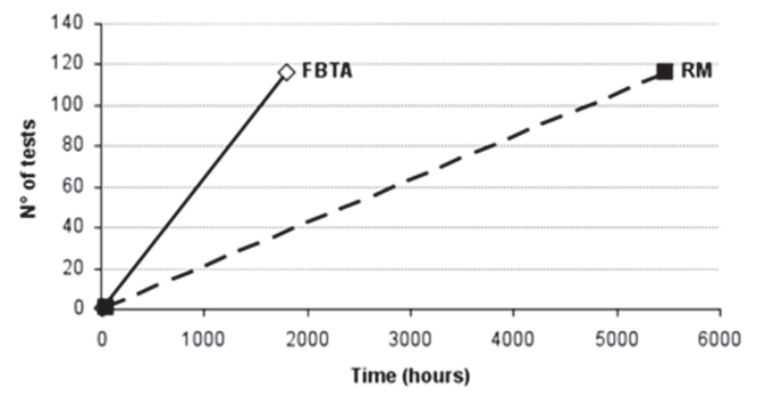

Fig. 8. Total time required to detect Escherichia coli contamination in all samples (Panel A) and trend of promptness of the analyses by FBTA and Reference Method (RM) (Panel B) (Berlutti et al., 2008b).

\subsection{BioTimer Assay to detect the susceptibility of bacteria in planktonic and biofilm lifestyle to antibiotics}

Staphylococcus aureus and S. epidermidis biofilm represent great challenge for medicine as they are involved in device- and specially catheter-related infections (Falagas et al., 2007). Usually, antibiotic treatment of catheter-related infections is based on antibiotic susceptibility tests performed on planktonic form of the clinical isolates instead on biofilm. It is well known that microorganisms organized in biofilm exhibit higher levels of antibiotic resistance than in planktonic form, so that a great part of therapeutic regimens based on susceptibility of planktonic forms fails to eradicate biofilm infections (Carratalà, 2002; Pascual et al., 1993). Therefore, it is imperative to set up a reliable method to detect antibiotic susceptibility of clinical isolated bacteria in biofilm, rather in planktonic lifestyle. At now, few methods are available to determine microbial antibiotic susceptibility of bacteria in biofilm. The Calgary Biofilm Device is the most popular method (Ceri et al., 1999), determining the minimal biofilm eradication concentration (MBEC) as the concentration of antibiotic required killing $100 \%$ of bacteria in biofilm. Unfortunately, none of these methods detects the actual number of bacteria in biofilm used as inoculum in MBEC tests. As inoculum size influences the results of susceptibility tests (Egervarn et al., 2007), MBEC values determined using the above mentioned methods, could be mistaken.

BTA has been applied to evaluate antibiotic susceptibility of Staphylococcus biofilm and for the contemporaneous enumeration of viable bacteria after exposure to sub-inhibitory doses 
of antibiotics (Pantanella et al., 2008). For these experiments, BT-PR Muller Hinton (BT$\mathrm{PRMH}$ ) specific reagent has been set up to reliably determine antibiotic activity, and a specific correlation line has been determined (Table 1). Moreover, a work flow of BTA method to determine the minimal inhibitory concentration of a 24-hour-old Staphylococcus biofilm has been presented (Fig. 9).

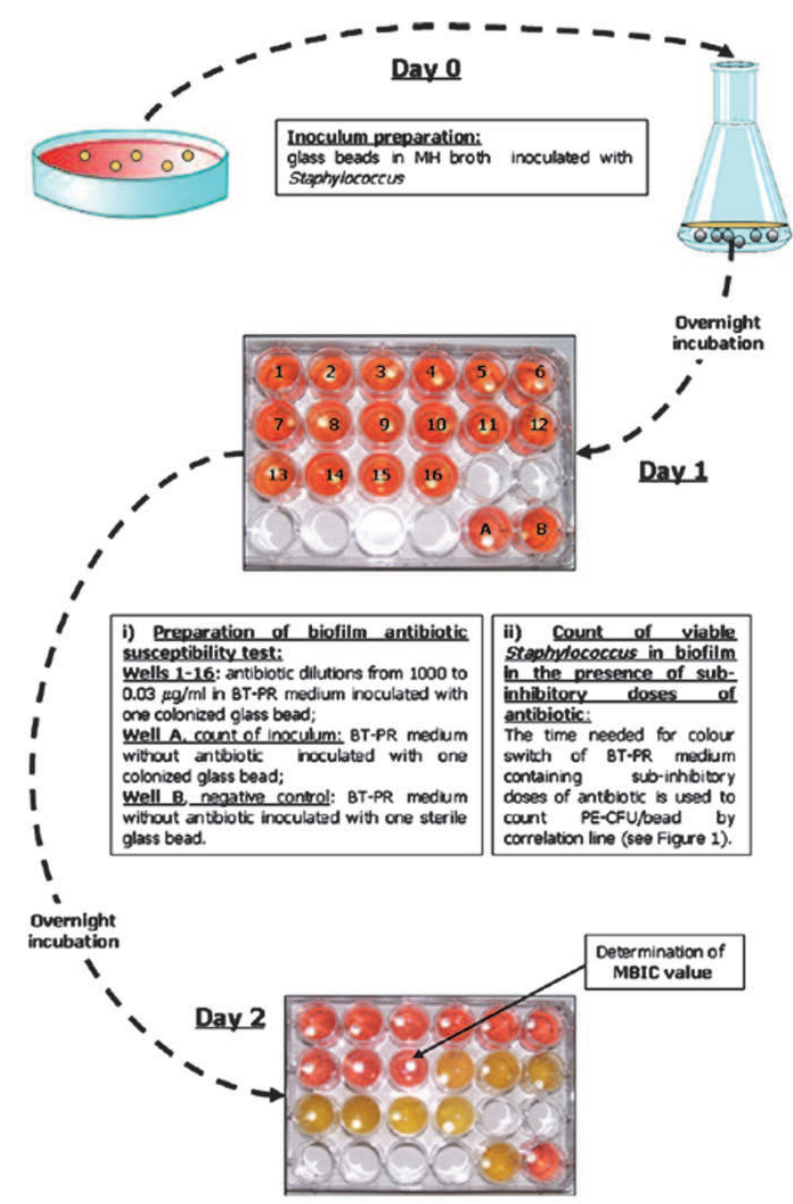

Fig. 9. Work flow of BioTimer Assay to determine the minimal inhibitory concentration of a 24-hour-old Staphylococcus biofilm (Pantanella et al., 2008).

Preliminary results obtained using BTA and reference antibiotic susceptibility test in evaluating MICs of planktonic Staphylococcus agree at 100\% thus demonstrating the BTA reliability. Thereafter, BTA has been applied to study susceptibility of Staphylococcus biofilm to four antibiotics chosen as prototypes of different mechanisms of action. In this set of experiments, Staphylococcus biofilm has been developed on glass beads for 24, 48, and 72 hours. Colonized glass beads has been used as inoculum in antibiotic susceptibility assays in BT-RPMH specific reagent (Table 1). 
Antibiotics susceptibilities determined by BTA confirmed a greater resistance of biofilm than of planktonic form according to the worldwide accepted literature (Lewis, 2001). Unlikely to all antibiotic susceptibility tests, BTA is the first method allowing to know the number of viable bacteria in the presence of sub-MBICs of antibiotics. This peculiar ability of BTA method may have a great importance for clinicians in evaluating also the putative therapeutic impact of sub-inhibitory doses of antibiotics against bacterial biofilm as they may favor biofilm development (Mirani \& Jamil,, 2010)

Moreover, the possibility to count viable bacteria in biofilm could also be employed to study new anti-biofilm drugs. As matter of fact, the reported data show that antibiotics differently kill bacteria in biofilm and that the killing is dependent on biofilm age (Donlan \& Costerton, 2002). Sub-MBICs of gentamicin and ampicillin, for example, reduce the number of viable Staphylococcus at higher extent in younger than older biofilm unlikely to sub-inhibitory doses of ofloxacin and azithromycin (Pantanella et al., 2008). Therefore BTA could be useful adopted in a wide range of microbiological laboratories to determine MBECs as well to evaluate the anti-biofilm activity of new antibacterial drugs.

\subsection{BioTimer Assay to detect the microbiological quality of nano-particles to be in vivo administered}

Infectious disease is one of the most important causes of mortality. Despite the great life expectancy related to advanced health care, the increasing numbers of complicating healthcare infections remain a significant public health challenge. Biofilm lifestyle, more common than planktonic one, plays a crucial role in human health despite the therapeutic use of antibiotics (Brady et al., 2008; Bryers, 2008; Donlan \& Costerton,, 2002). Moreover, biofilmmediated infections are very difficult to treat when biofilm develops on medical devices and implanted biomaterials (Janatova,2000; Shunmugaperumal, 2010; Høiby et al., 2010). Therefore, the possibility to counteract bacterial colonization of medical device and biomaterial surfaces represents a crucial issue in human health. In the past few years nanotechnology has broken into Medicine as tsunami involving in researchers with different skills. Nano-structured materials have been recently proposed as pragmatic approach for the development of new biomaterials able to counteract bacterial colonization and biofilm development (Aslan et al., 2010). A fundamental prerequisite in studying bacterial adhesion and biofilm formation on abiotic surfaces is the quantitative evaluation of the actual bacterial number. The susceptibility of nano-structured medical devices and biomaterials to microbial colonization and biofilm formation has not been thoroughly considered as well as the sterility in process of manufacturing and storage of nano-structured medical devices. The underestimation of the potential risk of contamination by adherent bacteria and/or biofilm formation on nano-structured surfaces can lead to the unwanted onset of bacterial infections likely to what happened in the early biomaterial era.

The ability of $S$. mutans to adhere and form biofilm on glass beads coated with single wall carbon nano-tubes (SWCNTs-GBs) has been verified by atomic force microscopy (AFM) (Figure 10).

The number of S. mutans adherent on SWCNTs (3 hours of incubation) and the number of bacteria in biofilm (24 hours of incubation) has been detected by BTA. Results showed that BTA was reliable to evaluate the number of $S$. mutans in adherent and biofilm lifestyle to SWCNTs-GBs as well as to control the sterility of SWCNTs (Table 3). 

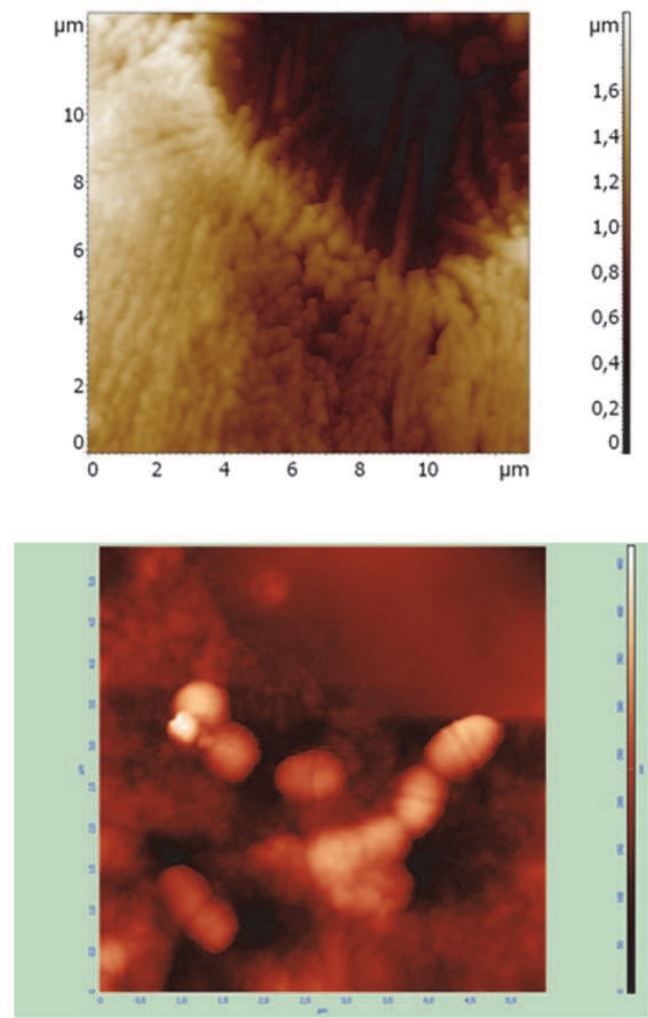

Fig. 10. Atomic force microscopy of sterile (A) and colonized (B) glass beads coated with single wall carbon nano-tubes.

\begin{tabular}{|c|c|c|}
\hline Bacterial inoculum $\left(\mathrm{N}_{0}\right)$ & $\begin{array}{c}\text { Number of bacteria adherent } \\
\text { to SWCNTs } \\
\text { (3 } \mathrm{h} \text { of incubation) }\end{array}$ & $\begin{array}{c}\text { Number of bacteria adherent } \\
\text { in biofilm to SWCNTs } \\
(24 \mathrm{~h} \text { of incubation })\end{array}$ \\
\hline 0 & 0 & 0 \\
\hline $3.2^{\star} 10^{5}$ & $1.3 \pm 0.2^{\star} 10^{5}$ & $3.4 \pm 0.5^{\star} 10^{8}$ \\
\hline $4^{*} 10^{6}$ & $1.8 \pm 0.1^{*} 10^{6}$ & $2.8 \pm 0.4^{*} 10^{8}$ \\
\hline $4.5^{\star} 10^{7}$ & $2.0 \pm 0.1^{*} 10^{7}$ & $3.1 \pm 0.3^{*} 10^{8}$ \\
\hline $4.2^{\star} 10^{8}$ & $2.5 \pm 0.3^{\star} 10^{7}$ & $3.7 \pm 0.1^{*} 10^{8}$ \\
\hline
\end{tabular}

Table 3. Enumeration of Streptococcus mutans in adherent and biofilm lifestyle on SWCNTsGBs.

\section{Conclusions and future perspectives}

The quantitative microbiological risk assessment is an actual problem for analytical assays and public health as well as for drug therapy to eradicate biofilm related infections. 
Despite the efforts to discover novel microbiological protocols involving multidisciplinary approaches, at now none validated method is available other than the CFU and MPN protocols that are unreliable to quantitative evaluate bacteria in adherent and biofilm lifestyle.

BTA utilizes original reagents specific for specific bacterial genera able to accelerate their metabolism. In fact, BTA exploits the synthesis of different metabolites produced by fermentative and non-fermentative bacteria evidenced by the switching of specific indicators. Moreover, this novel quantitative microbiological assay inversely correlates the time required for the switching of specific indicators with the number of bacteria present in the samples at time 0 . For this reason, even if BTA is a very sample microbiological method, it requires a deep study to accurately define the composition of the reagents and the indicators specific for the bacterial genera to be counted. Importantly, BTA does not require any manipulation of the samples as well as it is not limited by the size and nature of the samples.

On the basis of above reported data, even if BTA is not validated method, it should be considered a useful tool in counting bacteria in planktonic, aggregated and biofilm lifestyle present in fluid phase or adherent to abiotic or cell surfaces.

Therefore, BTA being a versatile method has been utilized to detect bacterial load on a variety of samples.

In the study of the adhesion efficiency of bacteria to different biomaterials, BTA has been successfully applied thus allowing a real control on new biomaterials to be in vivo applied.

In the food industry FBTA has been usefully applied to enumerate bacterial indicators of good hygienically practice without any manipulation of samples. E. coli contamination has been detected by BTA in significant shorter time than the reference methods thus allowing to rapidly applying corrective majors at CCPs, to prevent food hazard and decrease economic loss. Moreover, FBTA method has been also employed for the screening of food samples at different steps of the food chain and for the determination of the safety of final food products according to the recent Microbiological criteria for foodstuffs and to track food products.

Concerning clinical application, the principal advantage of BTA is related to its employment in the evaluation of antibiotic susceptibility of bacteria in biofilm lifestyle. At now BTA is the first method that not only allows to determine the bactericidal concentrations of antibiotics against biofilm, but also to count the number of bacteria resistant to antibiotic treatments. This aspect of BTA performance could be helpful in order to evaluate the efficacy of antibiotic treatment in eradicating biofilm.

Recently, BTA has been found to be reliable in quantitative evaluation of bacteria adherent to nano-coated materials. This last BTA performance should be particularly relevant in the microbiological risk assessment related to the present and increasing future use of nanomaterials to be in vivo applied.

Summarizing, BTA is an easy-to-perform and reliable biosensor which does not require a sophisticated apparatus as well as a complex experimental procedure after drawing correlation lines specific for each bacterial genus to be tested.

At now the main disadvantage of BTA is related to the lacking of a validated reference method, which limits the possibility to compare its reliability, efficiency, and sensitivity with reference methods, pivotal requisite for its validation and legal applications. 


\section{References}

Aslan, S., Loebick, C.Z., Kang, S., Elimelech, M., Pfefferle, L.D., Van Tassel, P.R. (2010). Antimicrobial biomaterials based on carbon nanotubes dispersed in poly(lactic-coglycolic acid). Nanoscale, Vol. 2, No. 9, pp. 1789-1794, ISSN 2040-3364, PMID 20680202

Berlutti, F., Pantanella, F., De Giusti, M., Tufi, D., Valenti, P., Boccia, A.(2008). FoodBioTimerAssay: a new microbiological biosensor for detection of Escherichia coli food contamination. Italian Journal of Public Health, Vol. 5, pp. 233-240, ISSN 1723-7815

Berlutti, F., Pantanella, F., Giona, M., Pagnanelli, F., Valenti, P. (2008) Indirect, easy-to-use and reliable method for counting bacteria in biofilm. Proceedings of Biofilms III: 3rd International Conference, p. 103, 6 - 8 October, Munich, Germany. Available from http:// files.dropbox.com/u/107928/proceedings_biofilmsiii_final.pdf

Berlutti, F., Rosso F., Bosso P., Giansanti ,F., Ajello, M., De Rosa, A., Farina, E., Antonimi,G., Valenti, P. (2003). Quantitative evaluation of bacteria adherent to polyelectrolyte hema-based hydrogels. Journal of Biomedical Materials Research. Vol. 67 , No. 1, pp. 18-25, ISSN 0021-9304, PMID 14517857

Bestul, M.B., Vandenbussche, H.L. (2005). Antibiotic lock technique: review of the literature. Pharmacotherapy. Vol. 25, No 2, pp.211-27, ISSN 0277-0008, PMID 15767236

Bochner, B.R., Savageau, M.A. (1977). Generalized indicator plate for genetic, metabolic, and taxonomic studies with microorganisms. Appl Environ Microbiol., Vol. 33, No. 2, pp. 434-444, ISSN 0099-2240, PMID 322611

Boulos, L., Prevost, M., Barbeau, B., Coallier, J., Desjardins, R. (1999). LIVE/DEAD BacLight: Application of a new rapid staining method for direct enumeration of viable and total bacteria in drinking water. J Microbiol Meth., Vol. 37, No 1, pp. 77-86, ISSN 0167-7012, PMID 10395466

Brady, R.A., Leid J.G., Calhoun, J.H., Costerton, J.W., Shirtli, M. E. (2008). Osteomyelitis and the role of biofilms in chronic infection. FEMS Immunol. Med. Microbiol., Vol. 52, No. 1, pp. 13-22, ISSN 0928-8244, PMID 18081847

Bryers, J.D. (2008). Medical biofilms, Biotechnol. Bioeng., Vol. 100, No. 1, pp 1-18, ISSN 00063592, PMID 18366134

Burne, R. A. (1998). Oral streptococci: products of their environment. J. Dent.Res., Vol. 77 No. 3, pp. 445-452, ISSN 0022-0345, PMID 9496917

Byun, M.W., Kim, J.H., Kim, D.H., Kim, H.J., Jo, C. (2007). Effects of irradiation and sodium hypochlorite on the micro-organisms attached to a commercial food container. Food Microbiology, Vol. 24, No. 5, pp. 544-548, ISSN 0740-0020, PMID 17367688

Carratalà, J. (2002). The antibiotic-lock technique for therapy of 'highly needed' infected catheters. Clin Microbiol Infect., Vol. 8, No. 5, pp. 282-9, ISSN 1723-7815, PMID 12047405

Ceri, H., Olson, M.E., Stremick, C., Morck, D.W., Read, R.R., Buret, A.G. (1999). The Calgary Biofilm Device: new technology for rapid determination of antibiotic susceptibilities of bacterial biofilms. J Clin Microbiol., Vol. 37, No. 6, pp. 1771-6, ISSN 0095-1137, PMID 10325322

Christensen, G.D., Simpson, W.A., Younger, J.J., Baddour, L.M., Barrett, F.F., Melton,bD.M., Beachey, E.H. (1985). Adherence of coagulasenegative staphylococci to plastic tissue culture plates: A quantitative model for the adherence of staphylococci to 
medical devices. J Clin Microbiol., Vol. 22, No. 6, pp. 996-1006, ISSN 0095-1137, PMID 3905855

De Giusti, M. , De Medici, D., Tufi, D., Marzuillo, C., Boccia, A. (2007). Epidemiology of emerging foodborne pathogens. Italian Journal of Public Health, Vol 4, No 1, pp. 2431, ISSN 1723-7815

Donlan, R.M., Costerton, J.W. (2002). Biofilms: survival mechanisms of clinically relevant microorganisms. Clin. Microbiol. Rev., Vol. 15, pp. 167-193, ISSN 0893-8512, PMID 11932229

Dorobantu, L.S., Gray, M.R. (2010). Application of atomic force microscopy in bacterial research. Scanning, Vol 32, No 2, pp. 74-96. ISSN 0161-0457, PMID 20695026

Egervarn, M., Lindmark, H., Roos, S., Huys, G., Lindgren, S. (2007). Effects of inoculum size and incubation time on broth microdilution susceptibility testing of lactic acid bacteria. Antimicrob Agents Chemother., Vol 51, No. 1, pp. 394-6, ISSN 0066-4804, PMID 17060527

European Centre for Disease Prevention and Control (2010). ECDC, ISSN 1830-6160, Available from http:/ / www.ecdc.eu.int/

Directive (EC) No. 7/2006 of the European Parliament and of the Council of 15 February 2006 concerning the management of bathing water quality and repealing Directive 76/160/EEC Official Journal of the European Union 4.3.2006 EN L 64/37

Falagas, M.E., Fragoulis, K., Bliziotis, I.A., Chatzinikolaou, I. (2007). Rifampicinimpregnated central venous catheters: a meta-analysis of randomized controlled trials. J Antimicrob Chemother., Vol 59 No. 3 pp. 359-369, ISSN 0305-7453, PMID 17255143

FDA, Food Protection Plan. Department of health and human services. Maryland: U.S. Food and Drug Administration; 2007. Available from www.fda.gov

Frioni ,A., Natalizi,T., Tendini, M., Fraveto, A., Pantanella, F., Berlutti, F., Pietropaoli, M., Passeri, D., Terranova, M. L., Rossi, M., Valenti, P. (2010). Biotimer Assay for counting bacterial biofilm. Biophysics and Bioengineering Letters, Vol. 3, No. 2, pp. 19, ISSN 2037-0199

Gandhi, M., Chikindas, M.L. (2007). Listeria: A foodborne pathogen that knows how to survive. Int J Food Microbiol., Vol. 113, No. 1, pp.1-15, ISSN 0168-1605, PMID 17010463

Goel, A.S. and Richter-Dyn, N. (1974). Stochastic models in biology, Academic Press New York, 1974. ISBN 0124192505

Gottenbos, B., van der Mei, H.C., Klatter, F., Nieuwenhuis, P., Busscher, H.J. (2002). In vitro and in vivo antimicrobial activity of covalently coupled quaternary ammonium silane coatings on silicone rubber. Biomaterials, Vol. 23, No. 6, pp. 1417-1423, ISSN 0142-9612, PMID 11829437

Høiby, N., Bjarnsholt, T., Givskov, M., Molin, S., Ciofu, O. (2010). Antibiotic resistance of bacterial biofilms. Int J Antimicrob Agents., Vol.35, No. 4, pp. 322-32, ISSN 0924-8579, PMID 20149602

Hope, C.K., Clements, D., Wilson ,M. (2002). Determining the spatial distribution of viable and nonviable bacteria in hydrated microcosm dental plaque by viability profiling. J Appl Microbiol., Vol. 93, No. 3, pp. 448-455, ISSN 1364-5072, PMID 12174043

International Organization for Standardization (ISO). Microbiology of food and animal feeling stuffs. Horizontal method for the enumeration of $\beta$-glucuronidase-positive 
Escherichia coli. Part.2: Colony-count technique at $44^{\circ} \mathrm{C}$ using 5-bromo-4-chloro-3indolyl $\beta$-D-glucuronide. ISO 16649-2:2001

Janatova, J. (2000). Activation and control of complement, inflammation, and infection associated with the use of biomedical polymers. ASAIO J., Vol. 46, No. 6, pp. 53-62, ISSN 1058-2916, PMID 11110295

John, T., Kopstein, A.B., John, O.C., Lai, C.I., Carey, R.B. (2001). In vitro adherence of Staphylococcus epidermidis to silicone punctual plugs and collagen implants. $J$ Cataract Refract Surg., Vol. 27, No. 8, pp. 1298-1302, ISSN 0886-3350, PMID 11524204

Gfeller, K.Y., Nugaeva, N., and Martin H. (2005). Rapid Biosensor for Detection of Antibiotic-Selective Growth of Escherichia coli. Applied and Environmental Microbiology., Vol. 71, No. 5, pp. 2626-2631, ISSN 0099-2240, PMID 15870354

Lee, D.G., Park, S.J., Kim, S.J. (2007). Influence of pipe materials and VBNC cells on culturable bacteria in a chlorinated drinking water model system. J Microbiol Biotechnol., Vol. 17, No. 9, pp. 1558-62, ISSN 1017-7825, PMID 18062238

Lewis, K. (2001). Riddle of biofilm resistance. Antimicrob. Agents Chemother., Vol. 45, No. 4, pp. 999-1007, ISSN 0066-4804, PMID 11257008

Madigan, M,, Martinko, J., Dunlap, P., Clark, D. (2008). Brock biology of microorganisms. 12th Pearson Ed. Ltd. UK. ISBN-10 0321536150

Merritt K., Gaind A., Anderson J.M. (1998). Detection of bacterial adherence on biomedical polymers. J Biomed Mater Res., Vol. 39, No. 3, pp. 415-422, ISSN 0021-9304, PMID 9468050

Mirani, Z.A., Jamil, N. (2010). Effect of sub-lethal doses of vancomycin and oxacillin on biofilm formation by vancomycin intermediate resistant Staphylococcus aureus. $J$ Basic Microbiol., Oct 21. [Epub ahead of print]) ISSN 0233-111X, PMID 20967790

Morbidity and Mortality Weekly Report. (June 2010). Summary of Notifiable Diseases United States, 2008. Vol. 57, No. 54, Available from http://www.cdc.gov/mmwr/pdf/wk/mm5754.pdf

Mohammadi, Z., Abbott, P.V. (2009). Antimicrobial substantivity of root canal irrigants and medicaments: a review. Aust Endod J., Vol. 35, No. 3, pp. 131-9, ISSN 1329-1947, PMID 19961451

Nair, P.N. (2004). Pathogenesis of apical periodontitis and the causes of endodontic failures. Crit Rev Oral Biol Med, Vol. 15, No. 6, pp. 348-81, ISSN 1329-1947, PMID 15574679

Oliver, S.P., Jayarao, B.M., Almeida, R.A (2005). Foodborne pathogens in milk and the dairy farm environment: food safety and public health implications. Foodborne Pathog Dis, Vol. 2, No. 2, pp. 115-29, ISSN 1535-3141, PMID 15992306

Pantanella, F., Valenti, P., Frioni, A., Natalizi, T., Coltella, L., Berlutti. F. (2008). BioTimer Assay, a new method for counting Staphylococcus spp. in biofilm without sample manipulation applied to evaluate antibiotic susceptibility of biofilm. Journal of Microbiological Methods. J Microbiol Methods, Vol. 75, No. 3, pp. 478-84, ISSN 01677012, PMID 18721833

Pascual, A, de Arellano, E.R., Martı́nez-Martı́nez L et al (1993). Effect of polyurethane catheters and bacterial biofilms on the in vitro activity of antimicrobial agents against Staphylococcus epidermidis. J Hosp Infect, Vol. 24, No. 3, pp. 211-18, ISSN 0195-6701, PMID 8104211 
Ramalho, R., Cunha, J., Teixera, P., Gibbs, P.A. (2001). Improved methods for the enumeration of heterotrophic bacteria in bottled mineral waters. J Microbiol Methods, Vol. 44, No. 2, pp. 97-103, ISSN 0167-7012, PMID 11165338

Regulation (EC) No. 1441/2007 modified of EC Regulation No. 2073/2005 of the European Parliament and of the Council of 5 december 2007 on microbiological criteria of foodstaffs, Official Journal of the European Union 7.12.2007 L322/12.

Regulation (EC) No. 178/2002 of the European Parliament and of the Council of 28 January 2002 on laying down the general principles and requirements of food law, establishing the European Food Safety Authority and laying down procedures in matters of food safety. Official Journal of the European Union 1.02.2002 L31/1.

Regulation (EC) No. 2073/2005 of the European Parliament and of the Council of 15 november 2005 on microbiological criteria of foodstaffs, Official Journal of the European Union 22.12.2005 L338/1. Official Journal of the European Union 7.12.2007 L 322/12.

Regulation (EC) No. 852/2004 of the European Parliament and of the Council of 29 April 2004 on the hygiene of foodstuffs.Official Journal of the European Union 30.4.2004 L 139/1.

Ricucci, D., Siqueira, J.F. Jr (2010). Biofilms and apical periodontitis: study of prevalence and association with clinical and histopathologic findings. J Endod, Vol. 36, No. 8, pp. 1277-88, ISSN 0099-2399, PMID 20647081

Romeo, U., Palaia, G., Pacifici, L., Ripari, F., Gambarini, G., Moroni, C., Tarsitani, G., Petti,. S. (2003). Antimicrobial activity of Nd:YAG laser in endodontics. J Dent Res , Vol. 82 (Spec. Iss. B) 184, No 1378, ISSN 0022-0345

Rueckert, A., Ronimus, R.S., Morgan, H.W. (2005). Development of a rapid detection and enumeration method for thermophilic bacilli in milk powders. J Microbiol Methods, Vol. 60, No. 2, pp. 155-167, ISSN 0167-7012, PMID 15590090

Sandoe Jonathan, A. T., Wysome, J., Andrew, P., West, Heritage, J. and Wilcox, M. H.. (2006). Measurement of ampicillin, vancomycin, linezolid and gentamicin activity against enterococcal biofilms. Journal of Antimicrobial Chemotherapy, Vol. 57, No. 4, pp. 767-770, ISSN 0305-7453, PMID 16464896

Schwarz, F,, Aoki, A., Sculean, A., Becker, J. (2009). The impact of laser application on periodontal and peri-implant wound healing. Periodontol 2000, Vol. 51, pp. 79-108. ISSN 0906-6713, PMID 19878471

Shunmugaperumal, T. (2010). Microbial colonization of medical devices and novel preventive strategies. Recent Pat Drug Deliv Formul, Vol. 4, No. 2, pp. 153-73, ISSN 1872-2113, PMID 20236065

Telesca, V. (2010). Interaction of 810nm and 2940nm lasers with endodontic bacterial pathogens. Thesis in European Master Degree On Oral Laser Applications (EMDOLA), November 5, 2010, Tutors: Prof Umberto Romeo, Prof Francesca Berlutti, Dr Gaspare Palaia.

Thorpe, T.C., Wilson, M.L., Turner, J.E., Di Guiseppi, J.L.,Willert, M., Mirrett, S., Reller, L.B. (1990). BacT/Alert: An automated colorimetric microbial detection system. J Clin Microbiol, Vol. 28, No. 7, pp. 1608-1612, ISSN 0095-1137, PMID 2116451

Vacheethasanee, K., Marchant, R.E. (2000). Surfactant polymers designed to suppress bacteria (Staphylococcus epidermidis) adhesion on biomaterials. J Biomed Mater Res, Vol. 50, No. 3, pp. 302-312, ISSN 0021-9304, PMID 10737871 
Velusamy, V., Arshak, K.., Korostynska, O., Oliwa, K.., Adley, C. (2010). An overview of foodborne pathogen detection: In the perspective of biosensors. Biotechnology Advances, Vol. 28, No. 2, pp. 232-254, ISSN 0734-9750, PMID 20006978

Vidana, R., Sullivan, A., Billström, H., Ahlquist M., Lund B. (2010). Enterococcus faecalis infection in root canals - host-derived or exogenous source? Lett Appl Microbiol, Vol. 52, No. 2, pp. 109-15, ISSN 0266-8254, PMID 21155997

Wilks, S.A., Michels, H., Keevil, C.W. (2006). Survival of Listeria monocytogenes Scott A on metal surfaces: implications for cross-contamination. Int J Food Microbiol , Vol. 111, No. 2, pp. 93-98, ISSN 0168-1605, PMID 16876278

Wilks, S.A., Michels, H., Keevil, C.W. (2005). The survival of Escherichia coli O157 on a range of metal surfaces. Int J Food Microbiol, Vol. 105, No. 3, pp. 445-454, ISSN 0168-1605, PMID 16253366 


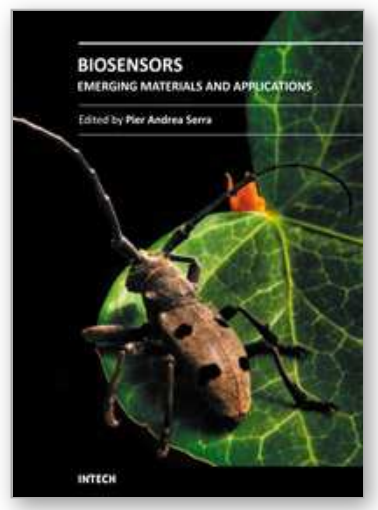

\author{
Biosensors - Emerging Materials and Applications \\ Edited by Prof. Pier Andrea Serra
}

ISBN 978-953-307-328-6

Hard cover, 630 pages

Publisher InTech

Published online 18, July, 2011

Published in print edition July, 2011

\begin{abstract}
A biosensor is a detecting device that combines a transducer with a biologically sensitive and selective component. Biosensors can measure compounds present in the environment, chemical processes, food and human body at low cost if compared with traditional analytical techniques. This book covers a wide range of aspects and issues related to biosensor technology, bringing together researchers from 19 different countries. The book consists of 27 chapters written by 106 authors and divided in three sections: Biosensors Technology and Materials, Biosensors for Health and Biosensors for Environment and Biosecurity.
\end{abstract}

\title{
How to reference
}

In order to correctly reference this scholarly work, feel free to copy and paste the following:

Maria De Giusti, Francesca Berlutti, Fabrizio Pantanella, Lucia Marinelli, Alessandra Frioni, Tiziana Natalizi, Daniela Tufi and Piera Valenti (2011). A New Biosensor to Enumerate Bacteria in Planktonic and Biofilm Lifestyle, Biosensors - Emerging Materials and Applications, Prof. Pier Andrea Serra (Ed.), ISBN: 978-953-307328-6, InTech, Available from: http://www.intechopen.com/books/biosensors-emerging-materials-andapplications/a-new-biosensor-to-enumerate-bacteria-in-planktonic-and-biofilm-lifestyle

\section{INTECH}

open science | open minds

\section{InTech Europe}

University Campus STeP Ri Slavka Krautzeka 83/A 51000 Rijeka, Croatia Phone: +385 (51) 770447 Fax: +385 (51) 686166 www.intechopen.com

\section{InTech China}

Unit 405, Office Block, Hotel Equatorial Shanghai No.65, Yan An Road (West), Shanghai, 200040, China 中国上海市延安西路65号上海国际贵都大饭店办公楼405单元 Phone: +86-21-62489820

Fax: +86-21-62489821 
(C) 2011 The Author(s). Licensee IntechOpen. This chapter is distributed under the terms of the Creative Commons Attribution-NonCommercialShareAlike-3.0 License, which permits use, distribution and reproduction for non-commercial purposes, provided the original is properly cited and derivative works building on this content are distributed under the same license. 